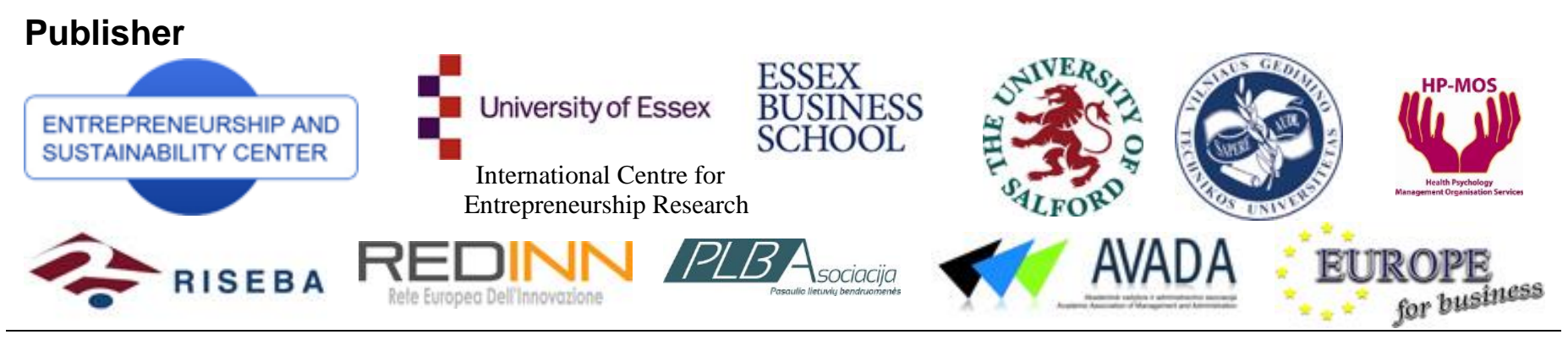

\author{
The International Journal \\ ENTREPRENEURSHIP AND SUSTAINABILITY ISSUES \\ ISSN 2345-0282 (online) http://jssidoi.org/jesi/aims-and-scope-of-research/ \\ 2016 Volume 3 Number 3 (March) \\ ENTREPRENEURSHIP AND SUSTAINABILITY ISSUES \\ ISSN 2345-0282 (online) http://jssidoi.org/jesi/aims-and-scope-of-research/
}

\title{
THE IMPACT OF SERVANT LEADERHSIP ON LEADERSHIP SUSTAINABILITY: EMPIRICAL EVIDENCE FROM HIGHER EDUCATION IN SYRIAN UNIVERSITIES
}

\author{
SERENE DALATI \\ Arab International University, Ghabaghib, Daraa, Syria \\ E-mail:s-dalati@aiu.edu.sy; serene.dalati@gmail.com
}

\begin{abstract}
The purpose of this research paper is to develop a theoretical framework of sustainable leadership model which could be applied to assess Higher education academic and administrative staff perception and level of endorsement of significant leadership behaviours at Higher Education industry. Leadership sustainability is relatively a new trend which requires further examination. The sustainable leadership model comprises a set of leadership behaviours including visionary, team oriented and servant leadership. A theoretical model is established, clarifying the significance of selection of the abovementioned leadership behaviours. Planned Methodology, measurement, empirical testing and application of the theoretical model is investigated. A quantitative approach is employed to design a questionnaire survey to identify the appropriate conceptualisation of integrated leadership attributes and behaviour items. The competitive advantage of the theoretical model is characterised by the combination and integration of various characteristics and attributes of leadership and its relationship to leadership sustainability, a newly defined leadership dimension in the context of higher education. The model argues the significance of the abovementioned leadership dimensions in Higher Education industry, particularly among rectors, faculty deans, vice dean and heads of departments. Cronbach alpha Reliability test shows very strong internal consistency and significance. Higher Education industry is investigated in this research study selecting a convenience sample from Higher Education institutions. Descriptive analysis shows high level of endorsement of perceived leadership dimensions among academic and administrative staff. The regression analysis shows strong and positive significance of servant leadership on perceived sustainability leadership in higher education. The research paper emphasizes the significance of leadership dimensions including vision, influence, team building, and service in higher education industry in Private and Public universities.
\end{abstract}

Keywords: leadership sustainability, vision, teambuilding, servant leadership, higher education

Reference to this paper should be made as follows: Dalati, S. 2016. The impact of servant leadership on leadership sustainability: empirical evidence from higher education in Syrian universities, Entrepreneurship and Sustainability Issues 3(3): $269-281$.

DOI: http://dx.doi.org/10.9770/jesi.2016.3.3(4)

JEL Classifications: M10, O10

\section{Introduction}

Leadership in Higher Education is a significant area of research that requires further investigation. Furthermore, there is no significant research about leadership in higher education in Syria. The need for awareness and knowledge of effective managerial leadership behaviours which enhances successful visions and missions for Higher education institutions, effective communication and team building for academic and administrative managers, has become an increasingly important discipline in organisational pure as well as practical research. 
The increasing demand for college's principals, skilful and effective heads of departments requires attention to the field of leadership capacity building (Lambert, 2012). Challenges associated with stressful work environment, information overload, technological advancement and connectivity, battle for analytical and managerial talent and increasing ethical dilemmas have been among important factors stimulating the need for effective principals, deans and rectors, who acquire required effective leadership qualities and behaviours that could transcend cultural, geographical, political, racial and national aspects. Furthermore the concept of sustainable leadership is contemporary as few research is developed in the field of sustainable leadership. The purpose of this research paper is to develop a model of sustainable leadership behaviours and attributes to be applied in higher education measuring academic and administrative staff perception of Sustainable Leadership in Higher Education in Syria. The research suggests a theoretical framework investigating the impact of perceived outstanding leadership behaviours on leadership sustainability in Higher Education in Syria.

\section{Leadership Behaviours in Higher Education}

Joo et al (2014) investigated Bolman and Deal framework of leadership investigating a dean in a private university in Malaysia, applying LOS self-instrument which was administered to the dean, and LOS otherinstrument which was administered to 35 staff who were responding directly to her. Results of the study shows a difference in leadership orientation between self-assessment and other assessment. Results of the study also show that it is necessary for future deans to be trained for leadership skills to meet demands of the industry(Joo, Hee, \& Piaw, 2014).

Chibani and Chibani (2013) explored leadership styles among school principals applying the Leadership Orientation Questionnaire which has two dimensions: one is self-rated by principals, and the other is addressed to school teachers to rate their principals on two dimensions. These include leadership and behavior. The study is divided into two parts. The sample of the study in part one were 8 schools principals and 158 school teachers selected from four private schools and one public school in Lebanon. In part two the sample was selected from two school principals and 40 school teachers from different schools. Results of the study showed that school principals crucially need creativity while school teacher need training(Chibani \& Chibani, 2013).

According to Sotirofski (2011) there are internal and external factors to be considered when examining higher education institutions. One of these crucial factors is related to administrators' ability to exercise leadership qualities. The study examines the construct of instructional leadership in higher education institutions where a comparison between Turkish and Albanian universities' administrators is conducted. A questionnaire survey is administered among a sample of 613 lecturers in universities in Turkey and Albania. Results show no significant difference in the perception of administrator's instructional leadership roles, university mission, managing learning and teaching process. With regard to academic staff, there is a significant difference between Turkish and Albanian lecturers' perceptions of administrator instructional leadership, in the sense that Turkish lecturers have more positive perception than Albanians (Sotirofski, 2011).

\section{Higher Education in Syria}

Primary, secondary and Higher Education is provided by state in Syria. However a legislation applied in 2001 allowed for the formation of private schools and colleges. Public higher education institutions in Syria are state controlled and financed. This is achieved through ministry of higher education and the Higher education Council. There are six public universities, and over fifteen private universities, and six higher institutions and tens of intermediate vocational, professional and technical training institutions that are under the responsibility of the ministry of Higher Education. The most influential legislative reforms for higher education in Syria was the presidential decree no. 36 for the year 2001, which governs the work of private universities in Syria. The other legal framework that governs higher education in Syria is Law No. 6 for the year 2006. This law governs 
the work of public universities in Syria which is called "The University regulation Law". The new law gives more autonomy to universities with regard to staff appointment and promotions. The ministry of the Higher Education is striving to set priorities, set plans and implement them and continue the process of modernizing of HE industry in Syria (Al-ahmar \& Ahmar-dakna, 2009).

The prevalent organizational environment of Higher Education industry in Syria, particularly public universities, could be characterized by a traditional managerial approaches with strong bureaucratic environment, application of outdated methodologies, lack of individual recognition, lack of effective encouragement of outstanding performance; limited collaboration with international conferences and academic journals, and most important a turbulent political environment which goes back to the past five years, represented by a political and national crisis in Syria. Against this background, a theoretical framework of leadership sustainability in higher education is developed in this research.

\section{Sustainable Leadership in Higher Education}

Sustainable leadership is a newly defined term in organisational leadership research(Hargreaves 2007, Lambert 2012). The term was coined by Hargreaves and Fink where sustainable leadership was stressed as a leadership paradigm which "matters, spreads and lasts. It is a shared responsibility that does not unduly deplete human of financial resources and that cares for and avoids exerting damage on the surrounding educational and community environment (Hargreaves \& Fink, 2003).

According to Hargreaves \& Fink 2003 a model of Sustainable leadership in Higher education was developed which consists of seven components which includes depth, length, breadth, justice, diversity, resourcefulness and conversation. The term was introduced to develop a framework which could balance between short term organisational objectives and long term grand goal regardless the change of the individual leader represented by the institution rector or faculty dean or department head in the institution.

Lambert (2012) develops a model for sustainable leadership to be implemented as a tool for organisational capacity building in Higher Education institutions. The model consists of six components including capacity building in staff, strategic distribution, consolidation, building long term objectives from short term targets, diversity and conservation.

\section{Developing a Model of Leadership Sustainability in Higher Education}

The theoretical model examines a set of sustainable leadership behaviors and dimensions, which are building on prior research on leadership in organizations not exclusively in Higher Education sector. The model builds on a set of independent variables of outstanding leadership behaviors which are predicted to have an impact on perceived leadership sustainability

\subsection{Visionary Leadership}

The first component in the theory of sustainable leadership at Higher Education builds on prior research of outstanding leadership in organizations emphasizing the importance of vision in organizations (Tichy \& Devanna 1986, Bennis \& Biederman 2009, Conger \& Kanungo 1998, Yammarino et al. 1993, Kouzes \& Posner 1995, Conger \& Hunt 1999). Organisational vision is defined as a set of idealized future goals developed by the leader which represents purpose and values shared by followers who embrace ideology of the leader (Strange \& Mumford 2005, House 1999, Collins \& Porras 1994, Ergeneli et al. 2007). According to Zaccaro \& Banks (2001) to improve a business competitive advantage, managers and business leaders need greater strategic flexibility which is developed through several factors, two of which include firstly ability to manage change, and 
secondly developing organizational vision which could be translated into a strategic plan. Building on previous research on leadership in organisations, vision as a quality and competency possessed by leaders at higher education sector, is developed as the first component in sustainable leadership in Higher Education model. Visionary leadership reflects leader's ability to inspire and motivate followers, establishing clear image of the tasks and what could be done better in the future of the organization. Visionary leadership behaviour comprises subscales including (a) visionary, (b) future oriented, (c) performance oriented, (d) risk taker, (e) industry knowledgeable and (f)agent of change.

\subsection{Team oriented Leadership}

The second component emphasises the significance of teambuilding in Higher Education and the importance of developing team leaders who can play crucial roles at individual, departmental and institutional levels. House et al. (2004) define team-oriented leadership behaviour as a leadership variable which emphasizes effective teambuilding and accomplishment of common goals among team members. A team is composed of some number of relatively independent individuals who are connected together in a work activity and each have their own needs, goals and expected outcomes that motivate their behaviour (Day et al. 2004, Tolle 1988, Salas et al. 1992, Salas et al. 2005, Cannon-Bowers et al. 1993). Team-oriented leadership reflects ability and knowledge of teambuilding, establishing common purpose for team members and social collective identity for followers. Team oriented leadership behaviour comprises subscales including (a) team builder (b) collective (c) sensitive to team needs (d) role model ( e) communicative.

\subsection{Servant Leadership}

The third component emphasizes service, fairness, self-sacrifice and modesty as components of a sustainable leader. The dimension of servant leadership is originated from prior research demonstrating aspects (Greenleaf 1977, Graham 1991, Farling et al. 1999, Liden et al. 2015, Mittal \& Dorfman 2012). Servant Leadership behaviour reflects ability of building trust by selflessly serving others; stressing personal integrity and, sensitivity to the needs of stakeholders including larger society. Servant leadership behaviour comprises subscales including (a) just (b) sincere (c) humble (d) dependable (e) self-sacrificial.

\subsection{Leadership Sustainability in Higher Education}

The fourth illustrates perceived leadership sustainability as a characteristic quality and behaviour within leaders in higher education. Promoting and encouraging diversity as a behaviour and values in higher education setting would be represented by demonstrating leader's awareness of differences among individuals related to higher education including students, academic and administrative staff and stakeholders in general. Sustainable

leadership behaviours comprises subscales including (a) trustworthy (b) egalitarian (c) culturally aware (d) performance oriented (e ) self - interest transcendent. 


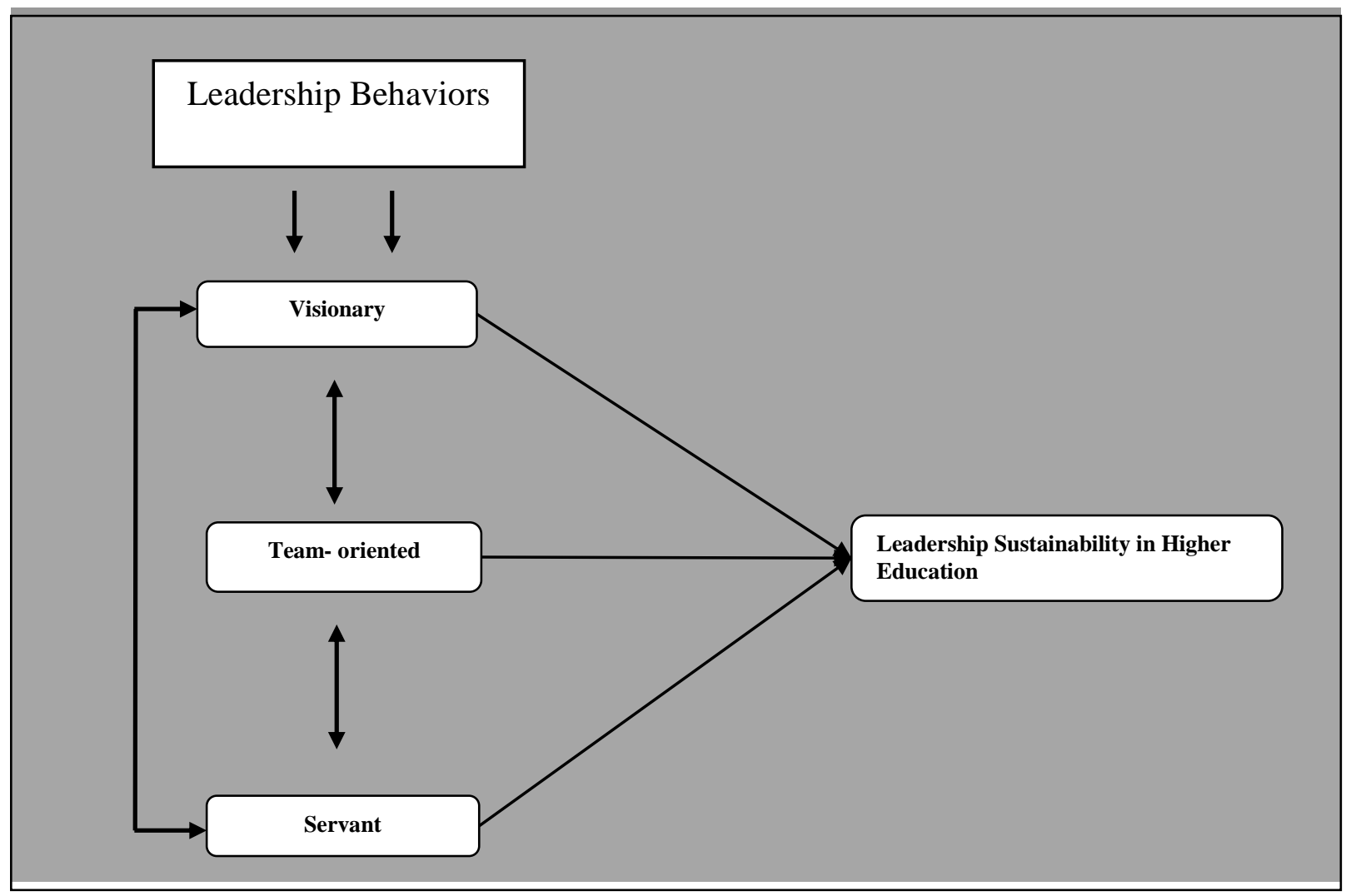

Figure 1: a Framework of Sustainable Leadership in Higher Education -Source: Researcher. Source: author

\section{5. Research Hypotheses}

According to Leithwood \& Duke (1999) there develops a set of leadership behaviors which are correlated with educational leadership. They include instructional leadership, moral leadership, transformational leadership, participative leadership, managerial leadership and contingency leadership approaches. Summarizing previous studies, a positive relationship between the prospective leadership behaviors is suggested.

H1

Visionary, team oriented and servant leadership behaviours are positively associated in the Higher Education environment.

H2

Visionary, team oriented and servant leadership are predicted to have a positive impact on leadership sustainability in Higher Education.

\section{Methodology Design}

The Managerial Leadership behaviors theoretical framework employed the application of a quantitative approach collecting primary data through self-administered questionnaire. The methodology of research is developed through the design of a self-administered questionnaire. According to Cooper \& Schindler (2014) advantages of 
self-administered survey include less cost, sample accessibility. Leadership behaviours scale is based and originated from prior leadership (Conger \& Kanungo 1998, Kouzes \& Posner 1995, Strange \& Mumford 2002, Kotter 1996, House, Paul J Hanges, et al. 2004, Mittal \& Dorfman 2012b). The questionnaire comprises a set of 36 items measuring perception of leadership behaviours and sustainability leadership.

\subsection{Sampling Design and Strategy}

Sampling design employed a convenience sampling strategy due to lack of resources to conduct a probability sampling strategy. The questionnaire survey was distributed to one private and one public Higher Education institutions. The total number of collected questionnaires is 68 responses. Only 56 of the questionnaires were employable due to lack of reliability in responses.

\section{Reliability and Validity of the Scale}

Cronbach alpha test is conducted to provide a measure of the internal consistency of the scales. Internal consistency describes the extent to which all the items measures the same construct and are connected to the interrelatedness of the items within the scale (Tavakol \& Dennick, 2011).Cronbach alpha Reliability test shows optimal reliability ranging from 0.87 to 0.91 which is to be considered an excellent indication.

Table 1 Cronbach alpha reliability test $(\mathrm{n}=56)$

\begin{tabular}{|l|l|l|}
\hline Variable Components & Number of Items & Alpha $(\boldsymbol{\alpha})$ without deleting any item \\
\hline Visionary & 7 & 0.89 \\
\hline Team oriented & 9 & 0.87 \\
\hline Servant & 10 & 0.91 \\
\hline Leadership Sustainability & 8 & 0.85 \\
\hline
\end{tabular}

\section{Descriptive Analysis}

\subsection{Demographic Profile of Respondents}

The demographical profile of respondents includes respondents' age, gender, type of institution, work experience in Higher Education, work experience in their present organizations examined in this study. Descriptive data shows that the average age of respondents is 43, work experience in Higher Education average mean is 11 years and work experience in current institutions is 8 years. Table 1 illustrates demographical data of respondents. $77 \%$ of the respondents were male, $23 \%$ female. $79 \%$ of respondents are $\mathrm{PhD}$ holders and $68 \%$ of academic staff are instructors (Table 2). 
Table 2. Demographic Profile of Respondents ( $\mathrm{n}=56)$

\begin{tabular}{|l|l|l|}
\hline Respondents Demographic Profile & f & \% \\
\hline Gender & & \\
\hline Male & 39 & 75 \\
\hline Female & 13 & 25 \\
\hline Higher Education Institution & & \\
\hline Private & 28 & 53 \\
\hline Public & 25 & 47 \\
\hline Faculty & & \\
\hline Business & 13 & 26 \\
\hline Pharmacy & 6 & 12 \\
\hline IT & 7 & 13 \\
\hline Economics & 23 & 45 \\
\hline Administration & 2 & 4 \\
\hline Education Level & & \\
\hline Bachelor & 7 & 13 \\
\hline Master & 3 & 5 \\
\hline PhD & 42 & 78 \\
\hline Other & 2 & 4 \\
\hline Academic Level & & \\
\hline Instructor & 23 & 56 \\
\hline Assistant Professor & 10 & 24 \\
\hline Professor & 8 & 20 \\
\hline Administrative Level & & \\
\hline Staff & 8 & 35 \\
\hline Head of Department & 6 & 26 \\
\hline Vice Dean & 6 & 26 \\
\hline Dean & 3 & 13 \\
\hline & & \\
\hline
\end{tabular}

\subsection{Descriptive Data Analysis}

Descriptive analysis illustrates managerial leadership behaviours profile investigated in Higher Education institution in Syria. Descriptive analysis shows that perceived leadership behaviours in HE institutions in Syria have high scores (Table 3).

Table 3. Descriptive Data Analysis for Leadership Behaviours ( $n=56)$

\begin{tabular}{|l|l|l|}
\hline Servant Leadership Behaviours Items & Mean & SD \\
\hline 1. Sincere and means what they say & 3.92 & 1.05 \\
\hline 2. Reliable and dependable & 3.92 & 1.05 \\
\hline 3. Stimulating others & 3.57 & 1.14 \\
\hline 4. Encourages others to use their mind and challenge beliefs & 3.50 & 1.26 \\
\hline 5. Willing to give time, money and resources & 3.54 & 1.05 \\
\hline 6. Tends to be good friend of subordinates & 3.66 & 1.11 \\
\hline 7. Has empathy for others & 3.69 & 1.07 \\
\hline 8. Tends to be helpful & 3.74 & 1.01 \\
\hline 9. Modest & 3.88 & 0.968 \\
\hline 10. Presents self in a modest way & 3.75 & 1.06 \\
\hline Visionary Leadership Behaviours Items & Mean & SD \\
\hline 1. Idealises future goals & 3.55 & 1.11 \\
\hline 2. Risk Taker & 3.41 & 1.24 \\
\hline 3. Ability to interpret and use knowledge of industry & 3.73 & 1.05 \\
\hline 4. Ability to set future oriented goals & 3.73 & 1.00 \\
\hline 5. Awareness of organisational barriers that may impair organisational goals & 3.87 & 1.06 \\
\hline
\end{tabular}




\begin{tabular}{|l|l|l|}
\hline 6. Vision of future for organisation & 3.67 & 1.14 \\
\hline 7. Reviews performance and plan of action & 3.38 & 1.22 \\
\hline Team oriented Leadership Behaviours Items & Mean & SD \\
\hline 1. ability to influence people to commit to team goals & 3.81 & 1.25 \\
\hline 2. aware of team members ability and what they could contribute to the team & 3.83 & 1.09 \\
\hline 3. sensitive to the abilities and emotional need of team members & 3.40 & 1.08 \\
\hline 4. Ability to communicate effectively and clearly with team members & 3.67 & 1.02 \\
\hline 5. works towards one collective team identity & 3.53 & 0.971 \\
\hline 6. makes sure attitude is clear to the team & 3.55 & 1.02 \\
\hline 7. ability to establish common ground of understanding with team members & 3.60 & 0.845 \\
\hline 8. acts as a role model for team members & 3.80 & 1.03 \\
\hline 9. Change team members attitude to advocate a proposed vision & 3.74 & 1.02 \\
\hline Leadership Sustainability & Mean & SD \\
\hline 1. Deserves trust and can be relied on to keep their word & 3.89 & 1.05 \\
\hline 2. Acts according to what is right or fair & 3.76 & 1.02 \\
\hline 3. Works jointly with others & 3.62 & 1.18 \\
\hline 4. Forgoes self-interest and make personal sacrifices & 3.30 & 1.17 \\
\hline 5. Performance and Standards of excellence & 3.57 & 1.12 \\
\hline 6. focuses on personal welfare of employees & 3.25 & 1.04 \\
\hline 7. aware of gender differences and treats team members with egalitarian approach & 3.61 & 1.03 \\
\hline 8. awareness of team members cultural backgrounds and values & 3.58 & 1.02 \\
\hline
\end{tabular}

\section{Correlation Analysis}

The correlation analysis shows positive and strong significance between the variables of the study and strong association between the aforementioned leadership dimensions. The correlation analysis shows strong association ranging from $r=0.71$ to $r=0.91$. The correlation analysis indicate significant relationship between leadership variables which supports the first hypothesis (Table 4).

Table 4. Means, Standard Deviation and Correlations $(n=56)$

\begin{tabular}{|c|c|c|c|c|c|c|}
\hline Variables & Mean & SD & 1 & 2 & 3 & 4 \\
\hline & 3.72 & 0.806 & 1 & & & \\
\hline 1-Servant Leadership & & & & & & \\
\hline 2-Visionary Leadership & 3.62 & 0.887 & $\begin{array}{l}0.821 * * \\
0.000\end{array}$ & 1 & & \\
\hline 3-Team oriented Leadership & 3.66 & 0.732 & $\begin{array}{l}0.780 \text { ** } \\
0.000\end{array}$ & $\begin{array}{l}0.830 * * \\
0.000\end{array}$ & 1 & \\
\hline 4- Leadership Sustainability & 3.57 & 0.765 & $\begin{array}{l}0.869 * * \\
0.000\end{array}$ & $\begin{array}{l}0.806 * * \\
.0000\end{array}$ & $\begin{array}{l}0.793 * * \\
0.000\end{array}$ & 1 \\
\hline
\end{tabular}

\section{Regression Analysis}

A regression analysis is conducted between a set of outstanding leadership behaviours which are employed in this study as the predictor variables. Leadership sustainability is examined as the outcome variable. Multiple regression analysis between Leadership behaviours and sustainability in Higher Education is conducted. In the first model, the multiple regression analysis indicates a significant relationship between servant leadership and leadership sustainability where the multiple regression test produces a standardised beta value of $0.86^{* *}, \mathrm{p}=$ 0.000 , confirming that servant leadership has an impact on leadership sustainability. 
In the second model the regression test indicates a significant relationship between servant leadership and leadership sustainability. The regression test produces a standardised beta value of $0.64 * *, p=.000$. The regression analysis also illustrates a significant relationship between team oriented leadership and leadership sustainability in higher education producing a standardised beta value of $0.29^{* *}, \mathrm{p}=.005$. The regression analysis confirms that servant and team oriented leadership have positive impact on Leadership sustainability. This result partially supports the second hypothesis. Table 5 illustrates the coefficient testing for hypothesis 2 regression analysis results reporting on standardised beta, F value and significance level (Table 5).

Table 5 Regression Analysis of Leadership behaviours and Leadership Sustainability (Dependent Variable: Leadership Sustainability)

\begin{tabular}{llll}
\hline Independent Variables & Beta & F & Sig \\
\hline Servant Leadership & $0.64 * *$ & 166.370 & 0.000 \\
\hline Team oriented Leadership & $0.29 * *$ & 98.759 & 0.000 \\
\hline
\end{tabular}

\section{Results and Discussion}

The descriptive analysis of the study shows generally high levels of perceived leadership behaviours among academic and administrative staff at Higher Education in Syria. The descriptive analysis results indicates high level of endorsement of the abovementioned behaviours and leadership styles. Results presented the research paper investigates descriptive analysis illustrated in table 3. With regard to managerial leadership dimensions in the study, few items were moderately rated. For example with regards to servant leadership, challenging beliefs and stereotypical approaches were moderately rated indicating that such a quality does not frequently exist in this culture or institution. That could be related to emphasize on religion and not encouraging provocative challenging questions. Risk taking is also an item which is perceived moderately, due to conservative aspect that characterizes Syrian Culture. The concept of challenging the status quo and motivating force for change is also perceived moderately in this research indicating possible lack or resistance or this quality. Leadership behaviours which include inspiring change, challenging thoughts and beliefs, questioning the status quo, are qualities that would need further consideration in the Syrian social and organisational environments. The correlation analysis shows positive and significant association between the variables of the study. The results of correlation analysis supports the first hypothesis. The regression analysis illustrates positive and significant relationship between servant and team oriented leadership and leadership sustainability indicting significant impact of servant leadership on leadership sustainability in higher education (Fig.2). 


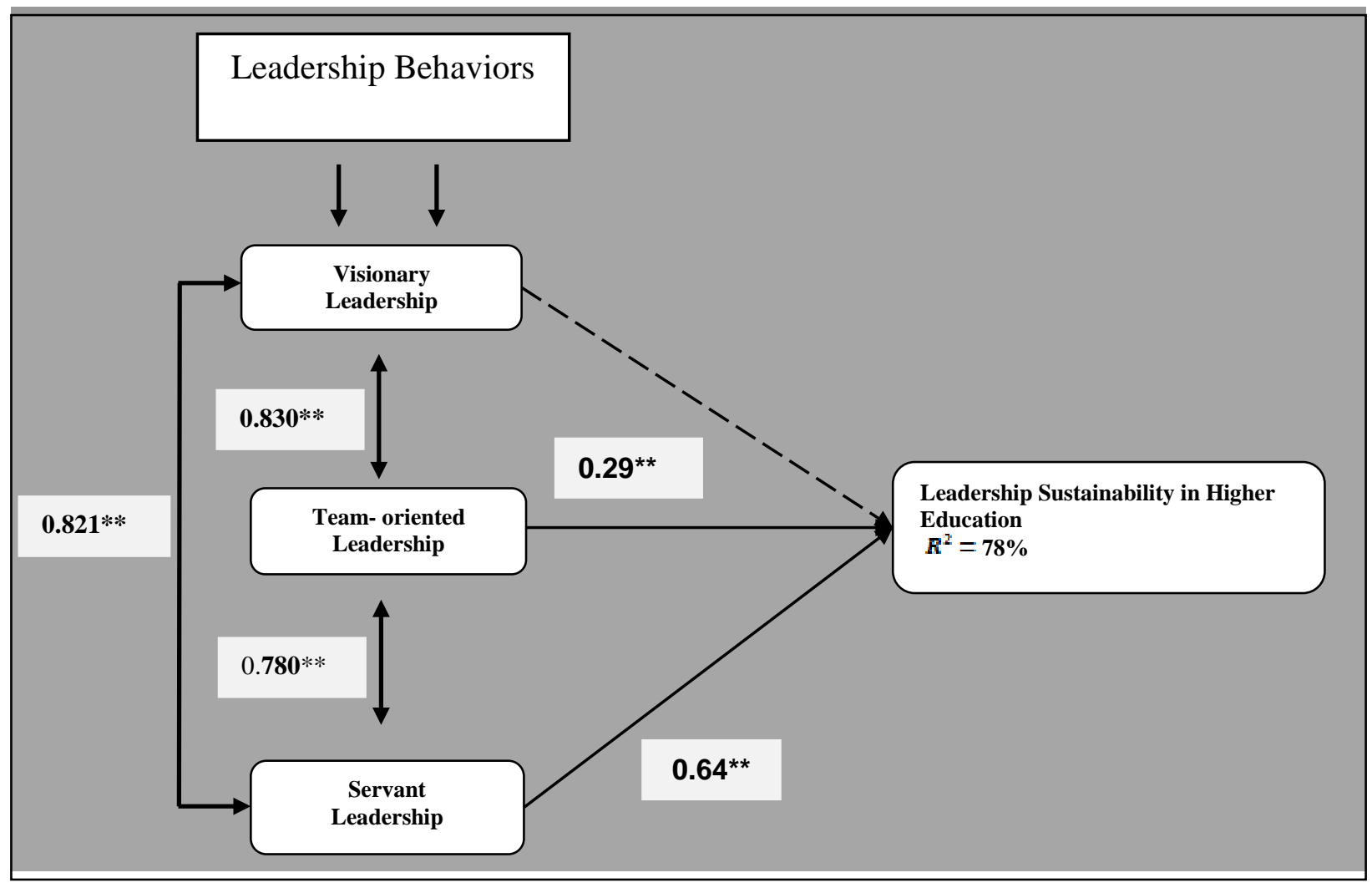

Figure 2: Regression Model for Leadership Behaviours and Leadership Sustainability Source: author

The model emphasises the significance of team dynamics and servant leadership to leadership sustainability in higher education. The research paper argues the importance of such behaviours in a sensitive and demanding approach at higher education industry. The importance and significance of the research has a future implication as these dimension has relationships with many work related factors, such as job satisfaction, commitment, work stress and organisational citizenship. Unfortunately there is lack of prior literature on leadership behaviours in Higher Education in Syria to compare or relate to.

According to Selamat et al. (2013) there is a positive relationship between transformational leadership and organisational commitment, emphasizing the role of principal in practicing transformational behaviour to stimulate teachers' organisational commitment. The application of the proposed leadership behaviours model in higher education context is an interesting application.

Another motivating notion that could be investigated in higher education environment is the relationship between leadership behaviours and organisational cynicism. According to Mete (2013) organisational cynicism in a new notion in the discipline of organisational behaviours, and represents person's negative attitudes towards his/her organisation. The result of the study shows significant effect of ethical leadership of faculty administration on academics' organisational cynicism.

Obviously the constructs of ethical, servant, and transformational leadership behaviours are crucial dimensions of leadership in higher education. Honesty, integrity, humility, service, self-awareness, self-actualization and 
role model building are crucial element in building mentor- student relationship, as well relationship between deans and rectors and their relationships with staff.

What could also be discussed in this research is related to the research environment that exist in Syria. During fieldwork and data collection stage few observation could be concluded in this context. The first observation is related mainly to administrative staff conceptual understating of leadership in the sense that they have good understanding of management but not leadership. When asked to bring back from their collective memory and experience in Higher Education an example of a co-worker or a superior who possessed leadership abilities and assess him/her according to the scale, most of administrative staff had difficulty of relating to the concept of a leadership in organisational environment. Whereas the concept of bureaucratic management is strongly clear in the minds of academic and administrative staff, the notion of leadership in organisations is not familiar. Some of the respondents related to their immediate managers and preferred rating them, although they were told to relate to a character who possessed leadership qualities and demonstrated leadership behaviours. The concept of perceived leadership was somehow too abstract for some of the respondents.

\section{Limitation of Research}

The most important and significant limitation of the study is related to sample size and strategy. The most important concern in this research is that the small size of sample could jeopardize the validity, reliability and generalisation of the results of the study. The size of the sample is 56 which could be considered as a good pilot test with significant results. Reliability test shows excellent results, however, the lack of validity tests and probability sampling strategy could risk robustness and generalizability of the research results.

The second limitation of the study is related to the simplicity of the framework which is building relationships between significant leadership dimensions and behaviours, without attempting to develop a sophisticated model that would build causal relationships between leadership as a crucial organisational variable with, variables which could in this context include, organisational commitment, motivation, academic job satisfaction, and individual performance.

\section{Future Research and managerial Implication}

Future research of outstanding leadership behaviors could investigate empirical testing of the model at a cross cultural approach. An empirical testing could include samples selected from different regions representing Western, Middle Eastern, European and Ocean Pacific regions. Future research could also investigate a contingency model of leadership and culture examining leadership behaviors that could be applied in specific cultures. A cross cultural sample could be selected from different regions taking in consideration harmonizing the target industry and unit of analysis of the research. Questionnaire translation could also investigate better enhancement techniques. Back translation could be conducted for cross research purposes (Brislin, 1970).

Significant implication could be the application or benefit of this research in a practical approach. Few lessons that were learnt from this research is lack of training and awareness of managerial leadership in organisational aspect. Training leadership skills programs to both academic and administrative staff could make a difference in organisational culture sense in the target institutions. What is desperately needed is a social and organisational culture which stimulates an empowering leadership approach versus a conventional bureaucratic approach.

\section{Conclusions}

The research paper examines the development of a theoretical framework of leadership behaviours and leadership sustainability in organisational approaches. The empirical testing of the model, which is selected from 
two Higher Education institutions, shows high level of perceived leadership behaviours endorsement among academic and administrative staff in Higher Education in Syria. The association between leadership shows strong and positive significance. The regression analysis shoes positive and significant relationship and positive impact of servant and team oriented leadership on leadership sustainability.

\section{Acknowledgement}

Thanks go to both academic and administrative staff in both target Higher Education institutions for their help and cooperation. Thanks also go to deans, vice deans and heads of departments who participated in research questionnaire survey.

\section{References}

Al-ahmar, A., \& Ahmar-dakna, S. (2009). THE NATIONAL PROJECT OR THE NATIONAL PROGRAMME : AN EVALUATION OF TEMPUS PROGRAMME CONTRIBUTION TO THE DEVELOPMENT OF THE HIGHER EDUCATION SECTOR IN SYRIA Rami Ayoubi. Universitas Stuttgart, (November).

Bennis, W., \& Biederman, W. (2009). The Essential Bennis. Harvard Business Review, (November), 465. Retrieved from http://books.google.com/books?id=U1qSEhnyx8AC\&pgis=1

Brislin, R. W. (1970). Back-Translation for Cross-Cultural Research. Journal of Cross-Cultural Psychology (Vol. 1). http://doi.org/10.1177/135910457000100301

Cannon-Bowers, J. A., Salas, E., \& Converse, S. A. (1993). Cognitive psychology and team training: Training shared mental models and complex systems. Human Factors Society Bulletin, 33, 1-4.

Chibani, W. Al, \& Chibani, P. H.- Al. (2013). Leadership styles of school principals in Lebanon : Multiple case study. Procedia - Social and Behavioral Sciences, 93, 174-176. http://doi.org/10.1016/j.sbspro.2013.09.173

Collins, J. C., \& Porras, J. I. (1994). SIOI ideology provides the glue together through time . Harvard Business Review, $74(5), 65-77$. http://doi.org/Article

Conger, J. a, \& Hunt, J. G. (1999). Charismatic and transformational leadership. The Leadership Quarterly, 10(2), $121-127$. http://doi.org/10.1016/S1048-9843(99)00017-X

Conger, J. A., \& Kanungo, R. N. (1998). Charismatic leadership in organizations. Charismatic Leadership in Organizations. http://doi.org/10.2307/2667134

Cooper, D., \& Schindler, P. (2014). Business Research Methods. Social Research, (12th Edition), 792. Retrieved from http://www.amazon.com/Business-Research-Methods-Alan-

Bryman/dp/0199284989\nhttp://130.209.236.149/headocs/31businessresearch.pdf

Day, D. V., Gronn, P., \& Salas, E. (2004). Leadership capacity in teams. Leadership Quarterly, 15(6), 857-880. http://doi.org/10.1016/j.leaqua.2004.09.001

Ergeneli, A., Gohar, R., \& Temirbekova, Z. (2007). Transformational leadership: Its relationship to culture value dimensions. International Journal of Intercultural Relations, 31(6), 703-724. http://doi.org/10.1016/j.ijintrel.2007.07.003

Farling, M. L., Stone, A. G., \& Winston, B. E. (1999). Servant Leadership: Setting the Stage for Empirical Research. Journal of Leadership \& Organizational Studies, 6(1-2), 49-72. http://doi.org/10.1177/107179199900600104

Graham, J. W. (1991). Servant-leadership in organizations: Inspirational and moral. The Leadership Quarterly, 2(2), 105-119. http://doi.org/10.1016/1048-9843(91)90025-W

Greenleaf, R. K. (1977). Servant Leadership. Leadership Excellence, 23, 20.

Hargreaves, A. (2007). Sustainable Leadership and Development in Education: Creating the future, conserving the past. European Journal of Education, 42(2), 223-233. http://doi.org/10.1111/j.1465-3435.2007.00294.x

Hargreaves, A., \& Fink, D. (2003). The Seven Principles of Sustainable Leadership by. Educational Leadership, 61(December), 8. Retrieved from http://www.marylandpublicschools.org/NR/rdonlyres/F7D49A8D-E9D0-4C49-9DE63A878BC9F1F4/18748/seven_principles.pdf

House, R. J. (1999). Weber and the neo-charismatic leadership paradigm. The Leadership Quarterly, 10(4), 563-574. http://doi.org/10.1016/S1048-9843(99)00032-6

House, R. J., Hanges, P. J., Javidan, M., Dorfman, P. W., \& Gupta, V. (2004a). Culture and Leadership. Culture, Leadership, and Organizations: The GLOBE Study of 62 Societies, 301-340.

House, R. J., Hanges, P. J., Javidan, M., Dorfman, P. W., \& Gupta, V. (2004b). Culture, Leadership , and Organizations. The GLOBE Study of $62 \quad$ Societies. $\quad$ Retrieved from http://books.google.de/books?id=_KsXEJQg9pkC\&dq=intitle:Culture+Leadership+I+Organizations\&hl=\&cd=1\&source=gbs_apil npapers2://publication/uuid/512B92AA-A29D-4E9F-9B45-59376DAF9E6F

Joo, M. T. H., Hee, T. F., \& Piaw, C. Y. (2014). Leadership Orientations of an Educational Leader in a Private University in Malaysia. Procedia - Social and Behavioral Sciences, 114(1990), 681-686. http://doi.org/10.1016/j.sbspro.2013.12.767 
Kotter, J. P. (1996). Leading change. Harvard Business School Press. Retrieved from http://books.google.co.uk/books?id=ib9Xzb5eFGQC\&printsec=frontcover\#v=onepage \&q\&f=falselnhttp://books.google.com/book

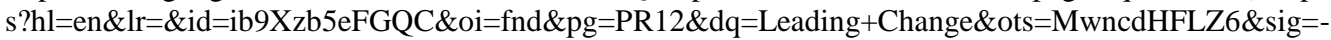
keCel5KTZpNVV5SJKbWTHJneeM

Kouzes, J. M., \& Posner, B. Z. (1995). The leadership challenge: How to keep getting extraordinary things done in organizations. San Francisco JosseyBass (Vol. 2nd). Retrieved from http://www.loc.gov/catdir/toc/onix07/95011314.html

Lambert, S. (2012). The perception and implementation of sustainable Leadership strategies in further education colleges. Journal of Leadership Education, 11(2), 102-120. http://doi.org/10.12806/V11/I2/RF6

Leithwood, K., \& Duke, D. (1999). A century's quest to understand school leadership. In Handbook of research on educational administration (pp. 45-73). http://doi.org/10.4324/9780203463383

Liden, R. C., Wayne, S. J., Meuser, J. D., Hu, J., Wu, J., \& Liao, C. (2015). Servant leadership: Validation of a short form of the SL-28. The Leadership Quarterly, 26(2), 254-269. http://doi.org/10.1016/j.leaqua.2014.12.002

Mete, Y. A. (2013). Relationship between Organizational Cynicism and Ethical Leadership Behaviour: A Study at Higher Education. Procedia - Social and Behavioral Sciences, 89, 476-483. http://doi.org/10.1016/j.sbspro.2013.08.880

Mittal, R., \& Dorfman, P. W. (2012a). Servant leadership across cultures. Journal of World Business, 47(4), 555-570. http://doi.org/10.1016/j.jwb.2012.01.009

Mittal, R., \& Dorfman, P. W. (2012b). Servant leadership across cultures. Journal of World Business, 47(4), 555-570. http://doi.org/10.1016/j.jwb.2012.01.009

Salas, E., Dickinson, T. L., Converse, S. A., \& Tannenbaum, S. I. (1992). Toward an understanding of team performance and training. In Teams Their training and performance (pp. $3-29)$ Retrieved from http://scholar.google.com/scholar?cluster=3558551026404344212\&hl=de\#0

Salas, E., Sims, D. E., \& Burke, C. S. (2005). Is there a "Big Five" in Teamwork? \n10.1177/1046496405277134. Small Group Research, 36(5), 555-599. Retrieved from http://sgr.sagepub.com/cgi/content/abstract/36/5/555

Selamat, N., Nordin, N., \& Adnan, A. A. (2013). Rekindle Teacher's Organizational Commitment: The Effect of Transformational Leadership Behavior. Procedia - Social and Behavioral Sciences, 90(InCULT 2012 ), 566-574. http://doi.org/10.1016/j.sbspro.2013.07.127

Sotirofski, K. (2011). Comparing the educational leadership roles of Albanian and Turkish higher education institutions administrators. Procedia - Social and Behavioral Sciences, 15, 3560-3565. http://doi.org/10.1016/j.sbspro.2011.04.335

Strange, J. M., \& Mumford, M. D. (2002). The origins of vision. Charismatic versus ideological leadership. Leadership Quarterly, 13(4), 343-377. http://doi.org/10.1016/S1048-9843(02)00125-X

Strange, J. M., \& Mumford, M. D. (2005). The origins of vision: Effects of reflection, models, and analysis. Leadership Quarterly, 16(1), 121-148. http://doi.org/10.1016/j.leaqua.2004.07.006

Tavakol, M., \& Dennick, R. (2011). Making sense of Cronbach's alpha. International Journal of Medical Education, 2 , 53-55. http://doi.org/10.5116/ijme.4dfb.8dfd

Tichy, N. M., \& Devanna, M. A. (1986). The transformational leader. Training \& Development Journal, 40(7), 27-32. http://doi.org/10.5465/AME.1987.4275914

Tolle, E. F. (1988). Management team building: Yes but! Engineering Management International. http://doi.org/10.1016/01675419(88)90006-3

Yammarino, F. J., Spangler, W. D., \& Bass, B. M. (1993). Transformational leadership and performance: A longitudinal investigation. The Leadership Quarterly, 4(1), 81-102. http://doi.org/10.1016/1048-9843(93)90005-E

Zaccaro, S. J., \& Banks, D. (2001). Leadership, vision, and organizational effectiveness. In organizational leadership: Understanding the performance imperatives confronting today's leaders (pp. 181-218).

Dr. Serene DALATI is the Head of Management Department and a senior lecturer at the faculty of Business administration at the Arab International University, Syria. Dr. Dalati has obtained a PhD in Leadership, Organizational Culture and Job satisfaction in 2008 which was preceded by an MBA from Bangor University in 2002. Dr. Dalati teaches for areas in organizational Behaviour, Leadership, Culture and Job satisfaction. Fields of expertise of teaching also include Strategic Management, International Management, Marketing, and Entrepreneurial Small Business

This is an open access journal and all published articles are licensed under a

Creative Commons Attribution 4.0 International License

Copyright of Journal "Entrepreneurship and Sustainability Issues" (c) Entrepreneurship and Sustainability Center, All Rights Reserved 